January 2008

\title{
'No Right to Judge': Feminism and the Judiciary in Third Republic France
}

Sara L. Kimble

DePaul University, skimble2@depaul.edu

Follow this and additional works at: https://via.library.depaul.edu/snl-faculty-pubs

Part of the European History Commons, History of Gender Commons, Law and Gender Commons, Legal Commons, Legal Profession Commons, and the Women's History Commons

\section{Recommended Citation}

Kimble, Sara L.. (2008) 'No Right to Judge': Feminism and the Judiciary in Third Republic France. French Historical Studies. 609-641.

https://via.library.depaul.edu/snl-faculty-pubs/27

This Article is brought to you for free and open access by the School of Continuing and Professional Studies at Digital Commons@DePaul. It has been accepted for inclusion in School of Continuing and Professional Studies Faculty Publications by an authorized administrator of Digital Commons@DePaul. For more information, please contact digitalservices@depaul.edu. 


\title{
No Right to Judge: Feminism and the Judiciary in Third Republic France
}

\author{
Sara L. Kimble
}

In 1931 the Catholic feminist attorney Marie-Thérèse Moreau asked: "Why does France not have female judges?" ${ }^{1}$ Her query was prompted by a visit from Warsaw's leading juvenile court judge, Wanda Grabinska, who often traveled to France and spoke favorably of women's access to the judiciary. ${ }^{2}$ Grabinska was one of many women who, after World War I, could now vote and pursue the profession of her choice. Female judges could already be found in various countries including Poland, Germany, Lithuania, Sweden, Turkey, and the United States. ${ }^{3}$ Although France was among the first countries to graduate women from law schools and to admit women to the bar, Frenchwomen were among the last to enjoy equal opportunities in this profession.

At the fin de siècle Jeanne Chauvin, a doctorate in law and a lycée teacher, attempted to open the legal profession to women by bringing suit. The Cour de Cassation rejected her claim in 1897 and justified

Sara L. Kimble is assistant professor of history at the University of Northern Iowa. She is completing a book tentatively titled Justice Redressed: Women and the Social Uses of the Law in Modern France, 1900-1946.

The author wishes to thank Rachel Fuchs, Sarah Hanley, Karen Offen, Lars Peterson, and the journal's anonymous reviewers for their helpful criticism and suggestions. The Radcliffe Institute and the University of Northern Iowa provided generous research support.

1 Marie-Thérèse Moreau, "Une conférence d'une femme magistrat," L'union nationale des femmes, Feb. 10, 1931, 2.

2 Marcelle Kraemer-Bach, "Fédération internationale des femmes avocats," La Française, Nov. 9, 1929; Kraemer-Bach, "L'enfance en danger moral," La Française, Dec. 30, 1933; Wanda Grabinska, "L'enfant devant le tribunal," in Première assemblée générale de l’Association internationale des juges des enfants: Journées des 26, 27, 28 et 29 juillet 1930 (Brussels, 1931), 52-69.

3 Maria Vérone, "Les femmes dans la magistrature dans le monde entier," Le droit des femmes, Feb. 1929, 46-47. Nazis prohibited German Jews from practicing law from June 1933 on, and all women were excluded from the profession from 1936 to 1945. The leading American female juvenile justice reformer was Miriam Van Waters, who maintained contacts in France, especially as a vice president of the International Association of Children's Magistrates (Schlesinger Library, Radcliffe Institute [hereafter SL], Miriam Van Waters Papers, box 47, folder 576). See Estelle B. Freedman, Maternal Justice: Miriam Van Waters and the Female Reform Tradition (Chicago, 1996). 
women's exclusion from the bar and judiciary on the grounds that they were disenfranchised and thus ineligible to serve in a "virile office." The independent socialist deputy René Viviani believed that women had a right to work in the profession for which they had been trained and so sponsored legislation to permit women to work as avocats. Under pressure from the Ministry of Justice, Viviani's bill did not include a request for women's access to the judiciary. ${ }^{4} \mathrm{His}$ colleagues agreed to support women's freedom to participate in the legal profession on the condition that this did not commit them to granting women either the right to vote or the right to become judges. ${ }^{5}$ Consequently, Viviani's bill became the law of December 1, 1900, that created a two-tiered legal profession by admitting women to the bar without making any provisions for their entrance into other related jobs normally open to law school graduates, from notary to magistrate. ${ }^{6}$

Over the next four decades, advocates for women's rights endeavored to equalize opportunities in the legal and juridical profession, yet their concerted effort did not bring success until 1946. This article asks why women in France were prevented for so long from serving as judges. To address this central question, this study considers several key aspects of the history of women and the judiciary from the early twentieth century, when women began making inroads as lawyers, to the moment when the National Constituent Assembly finalized egalitarian legislation and briefly beyond to the consequential reaction to this reform. During these phases, what strategies did reformers pursue to bring equality to the judiciary? How did reformers work with the National Assembly and other governmental bodies to further their cause? How did the conceptualization of gender roles on both sides inform the debates? How did the campaign for professional opportunities intersect with the broader women's rights movement? The historical record of this controversy is replete with lively debates, selective and comprehensive legislative efforts, and public appeals produced by political, academic, and professional circles.

This study of gender discrimination in the judiciary reveals how enduring stereotypes ultimately shaped the organization, functioning, and perception of the courts. The law, in turn, also influenced the social relations of the sexes, especially by legitimizing prejudicial cultural attitudes and justifying inequitable practices. The initial antidiscrimina-

4 Archives Nationales (hereafter AN), C 5659, dossier 1734.

5 Journal officiel (hereafter JO), Débats parlementaires, Sénat, Nov. 14, 1900, 839-40.

6 Sara L. Kimble, "Justice Redressed: Women, Citizenship, and the Social Uses of the Law in Modern France, 1890-1939" (PhD diss., University of Iowa, 2002). 
tion movement centered on cracking open the juvenile court judiciary, the most culturally appropriate site for the application of women's civic maternalism. ${ }^{7}$ The second phase of the campaign, which emerged after World War I, aspired to achieve equal treatment for women in both work and political rights. ${ }^{8}$ These stages indicate that the conflict concerning female judges evolved along with attitudes about women's rights in French society. To contemporaries, the act of granting women the "right to judge" signified women's civil and political equality, and the intransigence exhibited by antiegalitarians was another way to forestall social change. The question of feminism lies at the heart of the debate over whether and when France would permit female judges. Writ large, the opposing sides represented, on the one hand, a conservative ideology with the tendency toward maintaining women's traditional role in reproduction and domesticity and, on the other hand, a movement to promote the republican ideals of meritocracy and equality.

Female lawyers, the most vigorous and persistent campaigners to open the judiciary to women, saw their cause as connected to advancing women's rights, the welfare of defendants, and the needs of the nation. They faced an opposition that insisted on women's inferiority and resorted to a convenient claim that political rights were a prerequisite for admission to the judiciary. ${ }^{9}$ Judicial reformers also struggled against the fact that married women's civil rights-including their right to work, to appear in court, and to contract-were subject to spousal approval under the Civil Code..$^{10}$ While these constraints were viewed increasingly as anachronistic, they constituted a bulwark against the claims for women's judicial eligibility. The reform movement was disadvantaged not only by law but also by culture. Cultural prejudices painted women as lacking the essential characteristics that judges typified: intellect, sangfroid, objectivity, and impartiality. Consequently, the battle to remove the gender requirement from the judiciary posed a challenge to male hegemony in society. The two camps could only

7 On feminism and maternalism, see Karen M. Offen, "Defining Feminism: A Comparative Historical Approach,” Signs 14 (1988): 119-57; and Françoise Thébaud, ed., Toward a Cultural Identity in the Twentieth Century, vol. 5 of A History of Women in the West (Cambridge, 1994), 405-15.

8 At the beginning of the twentieth century, women constituted 40 percent of the whitecollar sector and 32 percent of the workforce overall. See Joan W. Scott, "The Woman Worker," in A History of Women in the West, vol. 4, ed. Geneviève Fraisse and Michelle Perrot (Cambridge, 1993), 407; and Deborah Simonton, A History of European Women's Work, 1700 to the Present (London, 1998), 186.

9 On capacité politique in the 1930s, see Anne Boigeol, "Les femmes et les cours: La difficile mise en oeuvre de l'égalité des sexes dans l'accès à la magistrature," Genèses 22 (1996): 111.

10 The reforms enacted in 1938 did little to alter the legal powers of the husband. See Paul Smith, "The Eternal Minor: Feminism and the Civil Code," in Feminism and the Third Republic: Women's Political and Civil Rights in France (Oxford, 1996), 163-211. 
agree that what was at stake in this contest was nothing less than the future of women's rights and of gender relations.

\section{Women and the Professions}

Prior to the creation of the Ecole Nationale de la Magistrature in 1958, the Ministry of Justice administered the judiciary, accepting nominations for judgeships from the ranks of practicing lawyers or from the successful candidates who completed specialized exams. ${ }^{11}$ In theory, all male members of the bar could be called on to substitute for an absent judge. Although women were not explicitly banned from the judiciary, positive legislation was anticipated to authorize their participation. The first cadre of female lawyers in France, seeking to ease their transition and to bolster their public image, argued that their profession was ideal for many married women and compatible with raising a family. Maria Vérone, the fifth woman to join the Paris bar, commented that as a lawyer "a woman can live in perfect harmony in a man's milieu, do the same work as they do, and remain a good spouse and good mother." 12 Vérone also believed that women could "render great service" in the judiciary and would be rewarded with professional opportunities when they had proved to the public that they possessed a "spirit of equity" and "juridical sense." 13 The prevailing opinion, however, was better represented by the Catholic political economy professor Charles Turgeon, who thought that women were overly hasty in their desire to move into public occupations. While he accepted the logic of admitting women to the bar, he disapproved of further emancipation: "To speak frankly, women are wrong to claim all the virile offices at the same time. A little patience, if you please!" 14 Regardless of Turgeon's protest, the movement of female employees into the public sector was well under way.

Beginning in the nineteenth century, women made important advances in the liberal and public professions, especially as educators and inspectors. ${ }^{15}$ In her work on inspectrices, Linda L. Clark argues that

11 The Ecole Nationale de la Magistrature was intended "to restore the confidence of the French people in their legal system" (The French National School for the Judiciary [Bordeaux, (2005?)], 3). See also John Bell, Sophie Boyron, and Simon Whittaker, Principles of French Law (Oxford, 1998), 60-66; and Anne Boigeol, "La formation des magistrats: De l'apprentissage sur le tas de l'école professionnelle," Actes de la recherche en sciences sociales 76 (1989): 49-64.

12 Vérone is quoted in Jane Misme, "Votre profession vous plaît-elle? Offre-t-elle un avenir aux femmes?" Le matin, Aug. 12, 1911.

13 Maria Vérone, letter to the editor, Journal des femmes, Nov. 1909, 3.

14 Charles Turgeon, Le féminisme français: L'émancipation individuelle et sociale de la femme, vol. 1 (Paris, 1907), 467.

15 Linda L. Clark, Schooling the Daughters of Marianne: Textbooks and the Socialization of Girls in Modern French Primary Schools (Albany, NY, 1984); Rebecca Rogers, From the Salon to the Schoolroom: Educating Bourgeois Girls in Nineteenth-Century France (University Park, PA, 2005). 
female employees in the Ministry of the Interior successfully defended their positions in public administration and supported a larger role for women in civil service by using maternalist rhetoric. In this case, the maternalists contended that women's mothering skills singularly qualified them for roles in the public sphere, a position that ultimately undermined their primarily domestic identity. ${ }^{16}$ Women's participation in the socially acceptable fields of nursing and social work had similar effects. In her analysis of the professionalization of nursing, Katrin Schultheiss notes the devotional nature of nurses' duties and maintains that the service rendered by nurses to both patients and doctors greatly facilitated the acceptance of a female-dominated nursing corps. ${ }^{17}$ Evelyne Diebolt's research on social workers and philanthropists documents the fundamental role women played in the establishment of the medical-social apparatus at the heart of the twentiethcentury welfare state. ${ }^{18}$ Social workers, professionalized in 1908, were likewise perceived as altruistic, self-sacrificing, and maternal. The history of women's entrance into traditionally masculine professions suggests that successful integration often occurred when women's career choices did not appear to disrupt the primacy of their obligations to the household or to threaten masculine identity.

By the early twentieth century many government ministries had hired women as typists and clerks, though women experienced discrimination in terms of pay and promotion. Women were unevenly employed in the public sector because the law of December 29, 1882, authorized ministries to self-regulate. ${ }^{19}$ In 1910, for example, a typical ministry hired only a few hundred women, while public education employed more than seventy thousand. The Ministry of the General Post Office and the National Archives kept their salary costs low by strategically employing thousands of women. ${ }^{20}$ By contrast, the Min-

16 Linda L. Clark, "Feminist Maternalists and the French State: Two Inspectresses General in the Pre-World War Third Republic," Journal of Women's History 12 (2000): 32-59; Clark, The Rise of Professional Women in France: Gender and Public Administration since 1830 (Cambridge, 2000). On maternalism in a comparative context, see Seth Koven and Sonya Michel, "Womanly Duties, Maternalist Politics, and the Origins of Welfare States in France, Germany, Great Britain, and the United States, 1880-1920," American Historical Review 95 (1990): 1076-1108.

17 Katrin Schultheiss, Bodies and Souls: Politics and the Professionalization of Nursing in France, 1880-1922 (Cambridge, 2001).

18 Evelyne Diebolt, Les femmes dans l'action sanitaire, sociale et culturelle, 1901-2001: Les associations face aux institutions (Paris, 2001), 236-41; Diebolt, "Femmes protestantes faces aux politiques de santé publique, 1900-1939," Bulletin de la Société d'histoire du protestantisme français 146 (2000): 91-132; Brigitte Bouquet et al., eds., "Histoire des premières écoles de service social en France, 1908-1938," special issue, Vie sociale, nos. 1-2 (1995).

19 Simone Verdeau, L'accession des femmes aux fonctions publiques (Toulouse, 1942), 93.

20 Dominique Bertinotti, "Carrières féminines et carrières masculines dans l'administration 
istry of Justice employed fewer than three hundred women as prison guards, inspectors, instructors, and clerical staff. ${ }^{21}$ Internal politics and attitudes about gender roles influenced such personnel decisions. The Ministry of Justice remained opposed to hiring more women even as the demand for staff expanded with the growth of the state in the twentieth century.

Women's rights advocates called for an end to discrimination in all fields and argued that women's employment, especially in visible and nontraditional jobs, could have a positive effect on the overall position of women in society. Indeed, feminists monitored and documented women's intellectual and professional successes worldwide as signs of progress toward the equality of the sexes. ${ }^{22}$ Nancy F. Cott notes that lawyers, like doctors and clergy, functioned as "arbiters of custom and convention," and women experienced exclusion from professional opportunities as an affront and a reminder of the sexual hierarchy. ${ }^{23}$ From the belle epoque onward, the mainstream international women's rights movement called for the opening of the judiciary to women. ${ }^{24}$

\section{The Feminist Movement and the Juvenile Courts}

The campaign to allow women to serve as judges is linked to the history of the juvenile courts in France because reformers propagated the idea that women were best suited to preside over the juvenile courts first before entering other jurisdictions. The influential jurist Emile Garçon opined in 1911 that "no eloquent, persuasive speeches" were required to justify women's "obvious and logical role" in the juvenile courts. ${ }^{25}$ Others, many of them aligned with the philosophy of solidarism, called for women to be admitted as juvenile judges to help enact the doctrine of parens patriae, which put youth protection and moral rehabilitation at the center of the court's purpose. Over time a consensus grew among children's rights advocates, political leaders, and feminists that the

\footnotetext{
des postes et télégraphes à la fin du XIXe siècle," Annales: Economies, sociétés, civilisations 3 (1985): $625-40$.

21 Antoine Bonnefoy, Place aux femmes! Les carrières féminines administratives et libérales (Paris, 1913), 59, 303-5.

22 Laurence Klejman and Florence Rochefort, L'égalité en marche: Le féminisme sous la Troisième République (Paris, 1989).

23 Nancy F. Cott, The Grounding of Modern Feminism (New Haven, CT, 1987), 215.

24 See, e.g., Ada Bittenbender, "Women in Law," Report of the International Council of Women, Assembled by the National Woman Suffrage Association, Washington, D.C., U.S. of America, March 25 to April 1, 1888 (Washington, DC, 1888), 173-79.

25 Emile Garçon, "Quelques observations sur le projet de loi relatif aux tribunaux pour enfants," Revue politique et parlementaire 70 (1911): 72.
} 
courts were deficient without the application of women's civic-minded motherliness.

The new cohort of female lawyers was disproportionately assigned to represent juvenile defendants when the Department of the Seine created a precursor of the juvenile court system in 1907. This early judicial system was vulnerable to criticism on many fronts including the limited availability of police inspectors, the sensational and public nature of the trials, and the judges' perfunctory attention to the individual. ${ }^{26}$ Thousands of juvenile cases were heard annually, and during 1910 this court institutionalized 3,424 boys and 899 girls for indefinite periods. ${ }^{27}$ Few observers believed that the courts were fulfilling their protective goals, and feminist groups were among those who demanded immediate and comprehensive reforms. ${ }^{28}$

In 1911 Vérone, a regular defender of youth since she joined the Paris bar four years earlier, published a condemnation of the ad hoc approach to juvenile justice and called for the greater participation of women in the judiciary. Vérone, a freethinker with a socialist background, would emerge as the preeminent female lawyer of her generation and as a leader of the women's rights movement. ${ }^{29}$ From her professional experience she concluded that the judicial system treated children callously and ineffectively. Calling for action, she published the following criticism in the newspaper Le matin:

To understand the importance of legislative reform, one must attend a hearing of the eighth correctional court. On Mondays, at least fifty cases involving minors are heard by the court, and even if the crowd is limited to those who received summonses and subpoenas, the throng of defendants, witnesses, and parents overflows into the corridor, making it difficult for the defense counselors to reach their clients. Inside the chamber, there is an indescribable tumult: children are crying, mothers are weeping, fathers are protesting violently against judicial decisions that they do not understand; the children do not want to testify and must be carried bodily by the guards to take the stand as they cry out for their parents; the

26 Henri Rollet, "The Probation System in France," in Probation and Criminal Justice, ed. Sheldon Glueck (New York, 1933), 298.

27 Statistique générale de la France, Annuaire statistique de la France (Paris, 1912), 125, table 1; Patricia O'Brien, The Promise of Punishment: Prisons in Nineteenth-Century France (Princeton, NJ, 1982), 116.

28 Eugène Prévost and Paul Kahn, La loi sur les tribunaux pour enfants: Conditions d'application (Paris, 1914), 63; Maria Vérone, discussion on June 29, 1911, in Premier congrès international des tribunaux pour enfants, ed. Marcel Kleine (Paris, 1912), 346.

29 See Maurice Hamburger, Nos plus grands avocats (Paris, 1930), 170-76; Jean Maitron et al., eds., Dictionnaire biographique du mouvement ouvrier français, 44 vols. (Paris, 1964-97), s.v. "Vérone, Maria." 
girls collapse under the weight of their anxieties, and the women become ill; the presiding Judge Flory tries to reestablish order for a few minutes, but these lamentable scenes redevelop . . . as justice must carry on! ${ }^{30}$

Vérone observed that the juvenile trials were chaotic and fruitless for several reasons. First, the judges lacked a depth of experience in part because they worked no longer than a three-year tenure. The judges might also be poorly informed on case details because they relied on scanty evidence hastily compiled by the police. The panel of three judges also juggled heavy caseloads, could give only cursory attention to individuals, and often disagreed among themselves on sentencing. Vérone expressed little confidence in sitting magistrates and hoped for future ones who would consider such work an "honorable" assignment. Second, the judges received no training in relevant topics such as child psychology that might have aided the evaluation and sentencing processes. ${ }^{31}$ Third, the tools to prevent recidivism were few. Dispositions might include an indefinite sentence in correctional facilities such as La Petite Roquette, a boys' prison notorious in the nineteenth century for its cruel and tragically fatal use of solitary confinement. Alternatively, the delinquent might be committed to a colonie agricole (work farm), such as Mettray, or any number of private charitable institutions until reaching the age of majority. ${ }^{32}$ Neither state nor private reformatories were lauded for effectively rehabilitating youth.

The French League for Women's Rights (Ligue Française du Droit des Femmes, or LFDF) mobilized to campaign for legislation to establish juvenile courts that were autonomous and proficient. In June 1911 the LFDF's public meeting at the Musée Social promoted the anticipated benefits of female judges in the youth courts on the basis that women were more devoted than men to the rehabilitation of delinquents. They proffered an appeal to women's altruism: "Wives and mothers, it is your social duty to point the way to the most sensible and efficacious reforms. ... In all countries where women have the right to vote this reform . . . has already been realized . . . and criminality has diminished." The LFDF typically deployed a combination of maternalist and political rhetoric to argue that women's experiences in the domestic arena qualified them as experts for these new courts. ${ }^{33} \mathrm{By}$

30 Maria Vérone, “Les tribunaux spéciaux pour enfants," Le matin, May 27, 1911.

31 André Moufflet, "Le meeting du 27 juin 1911," Le droit des femmes, Jan. 1912, 12-15.

32 On institutional conditions, see Henri Gaillac, Les maisons de correction, 1830-1945 (Vaucresson, 1971). Clément Griffe's influential history of the TEA made a special note of Vérone's criticism of the courts (Les tribunaux pour enfants: Etude d'organisation judiciaire et sociale [Paris, 1914], 181).

33 Moufflet, "Meeting," 12-15. LFDF membership was one thousand by 1918. See Steven C. 
claiming that children deserved the more effective care that women could provide, feminists challenged male authority within the family, the judiciary, and the state. They believed that those most dedicated to children's welfare should preside over the future juvenile courts, and Vérone headed their list. ${ }^{34}$ The possibility of female judges also represented the opportunity to change the balance of power in favor of children's and women's interests. Vérone, the general secretary of the LFDF, had further ideas on how to apply other European approaches to rehabilitation based on an ethics-of-care model that nurtured children in familial environments and provided them with vocational training. ${ }^{35}$

The principal juvenile justice reformers readily acknowledged that women satisfied their essential criteria for juvenile magistrates. Women's suitability resulted from their experience with children and their appreciation of the moral and social stakes involved in treating at-risk youth. Moreover, reformers trusted women to adopt the new criminology that favored rehabilitation over punition. The vision of the future juvenile courts then under discussion included new staff such as specialized judges, court researchers (rapporteurs) to investigate juveniles' backgrounds and make sentencing recommendations to the judges, and probation officers (délégués) to monitor rehabilitation measures. At the 1911 First International Congress on the Juvenile Courts, the republican senator Ferdinand Dreyfus asserted that "women" and "feminism" could resolve children's social and psychological problems where men had previously failed. He called on women to "participate in this new jurisdiction, help us understand childhood, penetrate the obscurity of the infantile psyche; you, our wives and our daughters, look into the problems of these poor, little fleurs $d u$ mal, bruised and languishing, sometimes malevolent; with you and by your action, we will succeed in rebuilding their consciences and then return them to regular society." 36 The substitut du procureur général Pierre de Casabianca, a former senator, enumerated a judge's essential qualities: "a real intuition into the child's soul," a "heart," and sensitivity to children's points of view. Périclès Grimanelli, a former interior minister, advocated that the future probation system also employ women. ${ }^{37}$

\footnotetext{
Hause and Anne R. Kenney, Women's Suffrage and Social Politics in the French Third Republic (Princeton, NJ, 1984), 213.

34 Mary M. Lilly, “The French Women Lawyers," Case and Comment 21 (1914): 433.

35 Comité de défense des enfants traduits en justice de Paris, Procès-verbal de la séance solennelle de rentrée du 14 janvier 1914 (Paris, 1914). 18.

36 Quoted in Maria Vérone, "Premier congrès international," Le droit des femmes, Jan. 1912,

37 Périclès Grimanelli, report on June 29, 1911, in Kleine, Premier congrès international, 382.
} 
Women were potentially ideal candidates for the juvenile courts, some reasoned, because working on such cases lacked prestige and would have been undesirable for those who were not motivated, at least in part, by altruism. Dreyfus and Casabianca knew of few male judges who were interested in children's affairs and of still fewer who had expressed a willingness to leave their current positions to work with youth. Senator Philippe Berger argued resolutely for employing women as court auxiliaries because, he declared, "France is full of good mothers" who would take on duties that might be "disagreeable, exhausting, and difficult." 38 Liberal legal professionals claimed that female lawyers already constituted a corps of experienced and dedicated children's advocates from which juvenile magistrates might be recruited. Nevertheless, legal reform was required to create new opportunities for women. In 1911-12 the parliamentary debates on the question of establishing the tribunaux pour enfants et adolescents (TEA) held such promise.

\section{The Law of July 22, 1912}

The establishment of a judicial and social service system designed for the moral recovery of delinquent children ultimately required the modification of twenty-eight articles of the Penal Code, the redefinition of the minor's legal status, the allocation of court chambers, and the appointment of judges, délégués, and other staff to work on scores of cases. ${ }^{39}$ After several false starts and eighteen months of negotiation, Senator Dreyfus's bill won approval. The central innovation of the resulting law of July 22, 1912, was that disobedient or unlawful behavior by thirteen- to eighteen-year-olds was not criminal. Children under thirteen would not stand trial at all; instead, they would undergo mandatory "educative measures" as directed by a civil advisory council (chambre de conseil). ${ }^{40}$

During the legislative discussions, officials obliquely debated the question of women entering the judiciary through a related issue on the qualifications of the rapporteur. In theory, the rapporteur, a kind of magistrate with limited powers, compiled pretrial evidence to establish the guilt of the adolescent defendant, a responsibility wielded by

38 Kleine, Premier congrès international, 13-14, 349-51. Berger was a former Hebrew professor mentored by Ernest Rénan. See Jean Jolly, ed., Dictionnaire des parlementaires français (1889-1940) (Paris, 1962), s.v. "Berger, Philippe."

39 Monique Charvin et al., Recherche sur les juges des enfants: Approches historique, démographique, sociologique (Paris, 1996), 12.

40 See Pascale Quincy-Lefebvre, Une histoire de l'enfance difficile: Familles, institutions et déviances, 1880-fin des années trente (Paris, 1997). 
the juge d'instruction in adult cases. René Bérenger, the chair of the parliamentary commission, regarded the rapporteurs as a group of courtappointed rogatory agents who would conduct thorough inquiries into children's backgrounds to plumb the depths of the salient factors influencing their behavior. These pretrial investigations might also include searching households for criminal evidence, interrogating relevant parties, and ordering an autopsy in the event of a murder. Bérenger's extraparliamentary critics were displeased with many aspects of this plan including the possibility of authorizing women to do the work of an examining magistrate. ${ }^{41}$

The strongest supporter of potential female rapporteurs was the leftwing social-democrat senator Berger. He proposed to the Senate that women should serve in this capacity so they might apply their unique qualities of "heart" and "devotion" to conduct extensive interviews with children and their families. He described women's suitability for these inquiries by drawing a contrast between the sexes:

Woman will bring maternal sentiments [to the task] that will permit us to enter into the life and soul of the child, to understand him, and also to learn what regime to apply to enlighten him. It is in the nature of woman to be most devoted to these questions. Moreover, messieurs, and forgive me for saying so, it is easier to find women of heart and head who, by an absolute concordance of their lives with their principles, provide a high moral example to uplift those who have fallen. ${ }^{42}$

Berger justified his position on the basis of conventional conceptions of gender difference. He also lauded female lawyers as admirable, indefatigable, and positive influences on the current ad hoc juvenile court hearings. He opined that when future juvenile courts opened in smaller towns, they would need the right to draw on women in the absence of appropriate men. Finally, he encouraged an affirmative vote on his amendment as a service to the nation's children and the public good and to respect "women's altruism." ${ }^{3}$

The justice minister, Antoine Perrier, countered Berger's seemingly innocuous plan with a fierce and unequivocal answer: "It will not do to grant to women, under this disguised form, the authorization

41 Bell, Boyron, and Whittaker, Principles of French Law, 123. The deputy Paul Beauregard attacked the rapporteurs as "fake judges," while law professor Garçon argued that their power to search parents' homes violated adults' right to privacy. See JO, Débats parlementaires, Chambre des députés, July 12, 1911, 2824; Garçon, "Quelques observations," 72.

42 Berger also promoted legislation on weekly rest for workers (1906) and the suppression of the prostitution of minors (1907). See JO, Débats parlementaires, Sénat, May 19, 1911, 506.

43 Ibid. 
to become judges." Perrier insisted that women were prohibited from the judiciary by the law of 1900 and that their undisputed devotion to children could find other venues for expression. He warned senators that if Berger's proposal was ratified, "feminists" would capitalize on this opportunity to infiltrate all other courts. Evoking women's duty to the mission sociale, he declared: "The role that we leave to woman outside the halls of justice is still sufficiently great and attractive to her. In rejecting the amendment, you can be certain that she will not be deprived of filling it." Moreover, Perrier refused to tolerate any suggestion of a dispensation for female lawyers to enter the judiciary. Senator Dominique Delahaye, who thought Perrier was eliding significant differences between the rapporteur and the juge, interrupted with typical verve to call for an immediate discussion of women's admission to the judiciary. His request was ignored. Berger defended his amendment by insisting that he was not promoting a feminist agenda but only wanted what he thought was best for children. After all, his intention was to permit women to serve as court auxiliaries, not as associate or presiding judges. In a hurried vote, the senators approved Berger's amendment, and thus women were authorized to become rapporteurs in the new courts. ${ }^{44}$

How did the senators conceptualize gender roles in such a way that they ultimately carved a place for women in the face of the minister's claim that this breached the order of the judiciary? During the debate senators had revealed their sympathetic views of the public roles women played, especially in their capacities as philanthropists or attentive lawyers. The self-described antifeminist senator Emmanuel de Las Cases praised avocates for crafting a trusting rapport with delinquents. Las Cases, who believed that "woman's place is in the home," was nevertheless "almost converted" when he saw female lawyers assisting children with the devotion of "spiritual mothers." ${ }^{45}$ For his part, Senator Dreyfus commended Vérone as "a woman of great dedication" and as "our colleague" who could instruct everyone on the complexities of delinquency. ${ }^{46}$

Berger's amendment mandating inclusiveness for the new job of rapporteur generally gained public approbation, while Perrier's opposition did not. The jurist Clément Griffe explained that it is not "feminist" to "place women where they belong, looking after the children,

44 Ibid., 507-8. The admission of women was later completed by a circular in Jan. 1914. See Magdeleine Lévy, Les auxiliaires du tribunal pour enfants délégués et rapporteurs (Saint-Amand, 1933), $224 n 1$.

45 JO, Débats parlementaires, Sénat, Mar. 9, 1911, 238.

46 JO, Débats parlementaires, Sénat, May 18, 1911, 503. 
especially the youngest ones, who might otherwise be bruised in our big, maladroit hands." ${ }^{47}$ Le temps disapproved of Perrier's alignment with the "strict traditionalists" and concluded that since women had the right to defend clients, they were also competent to judge them. ${ }^{48}$ The novelist Lucien Descaves suggested that if the judicial edifice "trembled" with the arrival of women, then "repairs to its foundation" must be long overdue. ${ }^{49}$ For Marguerite Durand, the founder of the feminist daily newspaper La Fronde, this amendment was a tremendous victory: "It is the entrance of women into the judiciary," and "it is a real revolution from the point of view of law, legislation, custom, and prejudice. Feminists must mark this important occasion by publicizing their usefulness, not only for the feminist cause but to prove that this cause is tied to all social progress." "50 Vérone initially called this vote only a "triumph of common sense," rather than the "triumph of feminism," but later she optimistically celebrated the amendment as a guarantor of "the principle of the equality of the sexes." ${ }^{51}$ The critic Denise Moniez would write that the law assured a place for women whose presence in the courts hardly needed justification as they already "put all their force and grace into knowing how to be mothers." ${ }^{2}$ In truth, female rapporteurs posed little threat to gender hierarchies, as the central task of tactfully interviewing children on behalf of the justice system fell readily within commonplace ideas of women's presumably natural abilities. Moreover, eligibility was not a mandate for employment. Yet the response by the senators, jurists, and prominent feminists to this debate suggests that Perrier's traditionalist argument was beginning to lose its persuasive force. For the reform-minded, it was evident that women should have a role in the juvenile courts. Toward that end, Vérone was shortly thereafter appointed to the extraparliamentary commission on child protection. ${ }^{53}$

Everyone rightfully wondered whether full judicial access for women would soon be granted as Perrier had forecast, and feminists were eager to facilitate such a reform. In 1913, at the Tenth International Council of Women (Congrès International des Femmes), dele-

47 Griffe, Tribunaux, 267.

48 "Le féminisme au Sénat et au Palais," Le temps, May 20, 1911.

49 Lucien Descaves, "Les congrès des tribunaux pour enfants réclame la femme comme juge d'instruction," June 25, 1911, in Bibliothèque Marguerite Durand (hereafter BMD), 347.

50 Marguerite Durand, "A propos des tribunaux pour enfants: Le rôle des femmes," Les nouvelles, June 29, 1911.

51 Vérone, "Les tribunaux spéciaux pour enfants"; Vérone, "Les femmes rapporteurs aux tribunaux pour enfants," Le droit des femmes, Jan. 1912, 11.

52 Denise Moniez, Tribunaux d'enfants (Cahors, 1914), 14.

53 Cécile Brunschvicg, "France,"Jus suffragii, Aug. 1, 1913, 6. 
gates voted unanimously for women's equal access to legal and juridical careers on the same conditions as men. The attorney Agathe Dyvrande faulted the narrowness of the 1900 law for "establishing an inequality, prejudicial to women, between lawyers of the two sexes; it closes the door by which women have already entered into the sanctuary of justice itself." 54 The low numbers of European women pursuing legal studies, relative to other fields, was attributed to their exclusion from the judiciary, hostility from male colleagues, and poor salaries. ${ }^{55}$

When the new TEA opened to serve the Department of the Seine in March 1914, women were most often found in the same position as before the law of 1912: working as pro bono lawyers for minor defendants. Observers considered the new courts undervalued, evidenced by the fact that the first Parisian hearings were held in a "Spartan," even "undignified" room, without a separate waiting area for children. ${ }^{56}$ In the provinces many judges continued to work part time in ad hoc juvenile courts, and the new system was not mandated by law in the colonies until 1928 and 1933. ${ }^{57}$ The attorney Suzanne Grinberg believed that effective courts must adopt the American-style reeducation approach that offered social, moral, and educational assistance to children to prevent recidivism, rather than punishment. ${ }^{58}$ This approach was more popular among women than men in France. Henri Rollet, the first president of the children's courts for the Seine, who had affinities to women's rights groups, applied this more sensitive approach to his adjudications, favoring probation over confinement, only to be demoted in 1917 by traditionalist supervisors who judged him "excessively indulgent," a fault that they insisted threatened to "compromise the repressive efforts" of the courts. ${ }^{59}$ Rollet also advocated the employment of female judges, while his superiors did not. ${ }^{60}$

54 Mme. [Ghénia] Avril de Sainte-Croix, ed., Dixième congrès international des femmes: Oeuvres et institutions féminines, droits des femmes; 2 juin 1913, Paris (Paris, 1914), 577, 407, 397.

55 Ibid., 386-87, 396-97.

56 Georges Bourdon, "Les tribunaux pour enfants," Le Figaro, Mar. 7, 1914.

57 Martine Kaluszynksi, "Enfance coupable et criminologie," in Protéger l'enfant: Raison juridique et pratiques socio-juridicaires, XIXe-XXe siècle, ed. Michel Chauvière, Pierre Lenoël, and Eric Pierre (Rennes, 1996), 116. The 1912 law was not initially implemented in the colonies because the bill omitted the standard language, a lacuna that went uncorrected until 1928, with the island colonies of Martinique, Guadeloupe, and Réunion later added in 1933. Report by M. Monnerville, bill adopted without discussion by the Chamber on Nov. 16, 1933.

58 "Les tribunaux pour enfants," L'union morale, Jan. 1914, 401-4.

59 AN, BB6 (II) 1190, dossier Rollet.

60 The TEA did not produce a decline in criminality, but the number of children languishing in prisons did gradually fall as alternative treatments gained popularity. For example, the number of boys and girls sent to correctional penitentiaries fell to 3,205 in 1919, down by 26 percent from 1910, with boys the majority of those in custody. See Statistique Générale de la France, Annuaire statistique de la France (Paris, 1912-24), tables établissements d'éducation correctionnelle. 


\section{The Legacy of War and the Masculine Judiciary}

At the outbreak of war in August 1914, most feminists prioritized their national patriotism over their political goals, and the momentum of many of their campaigns stalled. Although the war opened a myriad of job and leadership opportunities in places ranging from munitions factories to mayoral offices, little changed substantively in the judiciary. During the war the justice system continued to run in the absence of the deployed men, as older judges (aged thirty-five to forty-seven) were put on reserve status and female lawyers and retirees did the remainder of the work. ${ }^{61}$ Women's wartime service tended to fuel a positive view of women's intellectual capability among the social elite ${ }^{62}$ Evolving attitudes were not enough, however, to change the Senate's position on expanding women's political rights. At the end of the war suffragists looked enviously to those countries where women's exclusion from the electorate had recently come to an end, including Russia, Britain, Austria, Germany, Czechoslovakia, Poland, and the United States. During the interwar period the French Senate would refuse, on four occasions, to ratify the voting rights bills that had met with deputies' approval.

Outside France women also benefited from the falling of gender barriers in many professions, including the law and judiciary. Marguerite Pichon-Landry, the leader of the National Council of Frenchwomen (Conseil National des Femmes Françaises, or CNFF), praised the opening of administrative and professional opportunities to women in other countries and argued that the French legislature must recognize the economic necessity of women's paid work for the survival of some families and the dignity of women. Like many others, she argued that the dual interests of the workforce and the family could be served simultaneously by admitting women into regular professions typified by, but not limited to, public service. ${ }^{63}$ In the politically unstable postwar decades feminists continued to target the judiciary as sorely in need of women's energetic and competent work, and their protests formed an intrinsic claim to equal citizenship.

In 1922 the Marseille LFDF attempted to undermine the authority of the masculine judiciary by casting doubt on men's fitness as juvenile magistrates. The attorney Marie-Thérèse Isnard questioned the credibility of an exclusively male TEA and rejected the supposition

61 Jean-Pierre Royer, Histoire de la justice en France: De la monarchie absolue à la République (Paris, 1995), 674-83.

62 Smith, Feminism and the Third Republic, 104.

63 Marguerite Pichon-Landry, "Résume du rapport présenté à la section d'études féminines du Musée social sur l'admission des femmes aux fonctions publiques," report, Musée Social, Mar. 16,1920 . 
that women could not be judges without first establishing their eligibility to become legislators and voters. A member of the Marseille bar since 1914, she believed that women's exclusion from the judiciary was illogical and asserted that the public would prefer female judges because their decisions would "always be inspired by the purest spirit of equity." 64 This attack on masculine partiality was a trope in feminist rhetoric designed to change cultural attitudes on gendered attributes.

Another seemingly promising moment for judicial reform came in the wake of the publication of Le tribunal pour enfants (1923), the first comprehensive study of the TEA's effectiveness. The unlikely author, Chloe Owings, an American Protestant social worker and wartime Red Cross volunteer, then a student at the Sorbonne, evaluated every stage of a juvenile defendant's experience from the pretrial detention to the court hearings to reclusion in a penitentiary colony or a convent. While researching her thesis Owings gained extraordinary access to the courts, to private religious and state confinement facilities, and to the records of the police and the service des moeurs (vice squad). She discovered widespread indifference to the TEA among judges and lawyers, who revealed that they would rather work on civil trials than juvenile ones because the former led to promotions, garnered esteem from colleagues, and could be profitable. She concluded that the court procedures failed to provide children with either rehabilitation or guidance and that the exclusion of women from the courts was a contributing factor. Owings strongly recommended that women should not be prevented from applying their "social housekeeping" skills to improve the status of delinquent youth. ${ }^{65}$ Moreover, she was alarmed that women remained almost entirely absent from the organizations that advised the courts. The influential Committee to Defend Children in the Justice System met regularly at the Parisian Palais de Justice and included only 1 woman, Vérone, among its 131 members. Such imbalance prompted Owings to ask: "Do women not wish to take part in these meetings, or do the men not admit them?" 66 Reformers applauded Owings's cri-

64 Marie-Thérèse Isnard, "De la nécessité de la femme magistrat," Le droit des femmes, May $1922,120-22$.

65 Chloe Owings, Le tribunal pour enfants: Etude sur le traitement de l'enfance délinquante en France (Paris, 1923), 317. Owings had arrived in France in 1916 with limited funds and little familiarity with the language, yet she contributed assiduously to the war relief efforts. She received a Certificate and Medal of la Reconnaissance Française aux Etrangers for her dedication. She stayed on after the armistice to teach social work at the pioneering professional training center of the Ecole Pratique de Service Sociale, founded in 1913 by the Protestant pastor Paul Doumergue, then studied sociology and political science with Sorbonne professors Paul Fauconnet and Célestin Bouglé. See SL, A-164, Chloe Owings Papers, unpublished MSS, 159-60.

66 Owings, Tribunal pour enfants, 322, 52-56. Vérone was well aware of her uniqueness on the council, and she commended the Paris battionnier Fernand Labori's willingness to break with 
tique, and the Académie des Sciences Morales et Politiques honored her thesis with a Prix Carlier.67

The effect of Owings's work, however, was to redirect the thrust of juvenile court reform away from the question of female judges and toward the creation of a corps of female social workers dedicated to assisting juvenile offenders. At the invitation of Judge Rollet, Owings, together with French philanthropists and social workers, organized a social casework apparatus to investigate the socioeconomic and medical conditions of each delinquent child, provide a substantive dossier to the judges, and help place troubled or needy children in appropriate facilities. ${ }^{68}$ The staff of the Social Service to Children in Moral Danger (Service Social de l'Enfance en Danger Moral, or SSE) completed the investigative work that had been designated for the rapporteurs but had become "a dead letter." ${ }^{9}$ Germaine Poinso-Chapuis, the minister of health and population from 1947 to 1948, later concluded that the SSE's work was invaluable; otherwise France would have been "at zero" in 1945 in terms of the rehabilitation of delinquent minors. ${ }^{70}$

\section{Interwar Campaigns for Judicial Reform}

As the SSE filled in service gaps for juvenile delinquents and suffrage activists reenergized their efforts, the National Assembly reconsidered advancing women's employment opportunities in the various branches of the legal profession. In the aftermath of the war, France faced a paucity of traditional candidates for the bench that renewed the discus-

\footnotetext{
"tradition" and "prejudices" to include her ("Les conquêtes du féminisme," Le droit des femmes, Mar. 1912, 6).

67 The prize is given to recognize the "most significant contribution to the field" in three years. See Lucien Lévy-Bruhl, "Rapport sur le concours pour le prix Carlier à décerner en 1923," Séances et travaux de l'académie des sciences morales et politiques 84 (1924): 115-16. Thanks to Pierre Kerbrat for providing this article. She also received the Médaille Pénitentiaire and became a chevalier in the Légion d'Honneur. See SL, A-164, Chloe Owings Papers, unpublished MSS, 250; and Knox College Archives, Galesburg, IL, Owings to Knox College president Albert Britt, Dec. 14, 1927.

68 Denise Lenain and Georges-Michel Salomon, "Une pionnière du service social, MarieThérèse Vieillot," Vie sociale 10-11 (1988): 418.

69 Dominique Dessertine, "Aux origines de l'assistance éducative les tribunaux pour enfants et la liberté surveillée, 1912-1941,” in Chauvière, Lenoël, and Pierre, Protéger l'enfant, 140.

70 Henriette Chandet, "Mme. Germaine Poinso-Chapuis: Députée des Bouches-duRhône," L'union nationale des femmes 15 (1946): 3. Aid existed in cities only; elsewhere inquiries into children's backgrounds were limited or even "nonexistent." See Marie-Sylvie Dupont-Bouchat and Eric Pierre, eds., Enfance et justice au XIXe siècle (Paris, 2001), 337. In 1952 the SSE changed its name to the Olga Spitzer Association, and a related organization exists today as La Fondation d'Enfance. See Pierre de Casabianca and Raoul Gabriel de Pascalis, Nouveau guide pour la protection de l'enfance traduite en justice, à l'usage des magistrats, des avocats et des auxiliaires des tribunaux pour enfants et adolescents (Paris, 1934), 358-60; Sarah Fishman, The Battle for Children: World War II, Youth Crime, and Juvenile Justice in Twentieth-Century France (Cambridge, 2002), 24; Diebolt, Femmes dans l'action sanitaire, 236-41; and Diebolt, "Femmes protestantes faces aux politiques," 91-132, 122-27.
} 
sions on possible roles for women. The postwar parliamentary debates no longer focused on the juvenile judiciary but ranged widely, from granting women narrow access to specific offices to legislating their complete professional equality.

In 1929 the prosuffrage Radical senator Louis Martin campaigned for an ultimately unsuccessful bill to admit women to the ubiquitous positions of notaire (civil law official) and avoué (court procedural officer). Martin reasoned that "in a nation where the number of women exceeds that of men by nearly two million, all fair-minded people accept the necessity of helping women to earn an honest living, whether in the liberal professions or the manual trades." Martin believed that "the most implacable adversaries" of potential female judges still approved of women entering these more humble but respectable legal positions. A 1928 survey had indeed documented this mixture of opinions. ${ }^{71}$ The glacial rate of cultural and legal change frustrated the feminist lawyer Odette Simon-Bidaux: "In France, a woman cannot vote in any election, obtain a passport without [spousal] authorization, enter the Bourse, assume hautes functions, leave the marital domicile, dress like a man, or render justice, but she could be guillotined." 72 When the Senate finally debated a bill on admitting women into the notariat in 1932, the egalitarian proposal was entirely overshadowed by the Radical senator Raymond Duplantier's tirade on the inferiority of women to men and their suitability only for the oldest profession. Although the bill was lost, suffragists organized to unseat Duplantier in the next election. ${ }^{73}$

While France resisted reforms, most central and eastern European nations opened their legal and juridical professions to women. Consequently, in 1928 female lawyers and judges formed the International Federation of Women in the Legal Careers (Fédération International des Femmes des Carrières Juridiques, or FIFCJ) to build solidarity. At the outset Estonian, Spanish, Polish, German, and Austrian women traveled to France to develop strategies to improve women's conditions, especially in family law, political rights, and job opportunities. This association brought internationally recognized activists to France, including the Madrid lawyer Clara Campoamor, who gave prosuffrage lectures, and the Polish judge Grabinska, who met with cabinet officials to lobby for women's access to the judiciary. ${ }^{74}$

In 1929 Agathe Dyvrande-Thévenin, president of the FIFCJ, put

71 Martin is quoted in Louis Saint-Laurens, L'accession de la femme aux fonctions judiciaires (Toulouse, 1931), 11-12; Maria Vérone, "Le féminisme au Sénat," L'oeuvre, Mar. 12, 1930.

72 Odette Simon-Bidaux, "En France la femme ne peut pas . . ., "Vu, Feb. 13, 1929.

73 See Smith, Feminism and the Third Republic, 137-39, 143-50.

74 BMD, dossier Clara Campoamor; Moreau, "Conférence." 
the question of why there were no female judges in France to the minister of justice, Lucien Hubert. In turn, Deputy Pierre Cathala, a Radical lawyer, agreed to sponsor a bill to admit women to the juvenile court judiciary. Before legislation could be introduced, however, the cabinet was shuffled, and neither Hubert nor Cathala could shepherd the reform through. ${ }^{75}$ The following year Grinberg, as president of the National Association of Female Jurists (Association des Femmes Juristes, or AFJ), renewed the appeal with Cathala, who was now the minister of labor. In this round she upped the ante and requested that all judicial posts be opened equally to female candidates. Grinberg, who first publicly announced her desire to work as a judge in 1909, characterized the current political and judicial system as riddled with hypocrisy, inconsistency, and injustice, all of which, she predicted, women's presence could ameliorate. The restrictions on her professional rights were a kind of prism through which she viewed social inequality: "[Women] have the same privileges, the same prerogatives, as men, with the one exception that they cannot complete a tribunal in the event that one of its members is detained or absent. Women cannot, even temporarily, render justice, except in the conseils de prud'hommes." 76 In this lament she called attention to the anomaly that since the early 1900s women could vote and be elected as judges in the labor arbitration courts of the conseils du travail (decree, September 17, 1900) and the conseil supérieur du travail (decree, March 14, 1903). ${ }^{77}$ In the case of the conseils de prud'hommes, women had been eligible to run for the elected positions since the laws of 1907 and 1908, and by 1930 women were serving as judges on an equal basis with men. ${ }^{78}$

The following year a more conciliatory Cathala appointed the Radical deputy André Bardon to introduce legislation to admit women to the judiciary on an equal basis. The deputies Bardon, Anatole de Monzie, and Camille Planche then proposed an amendment to this effect during a long debate devoted to the reorganization of the tribunaux de première instance (civil courts) in April 1930. The language of

75 "Les femmes juges," La Française, Nov. 23, 1929. See BMD, dossier Enfance délinquante, France (1899-1940). On the FIFCJ, see Sara L. Kimble, "Women, Law, and Friendship: Activities of the International Federation of Women in Legal Careers between the Two World Wars" (paper presented to the Social Science Historical Association, Minneapolis, Nov. 5, 2006).

76 Camille Bélilon, "Madame Grumberg," Journal des femmes, Aug.-Sept. 1909, 1; Suzanne Grinberg, "Le pouvoir judiciaire: Les auxiliaires de la justice," in La vie publique dans la France contemporaine (Paris, 1925), 43.

77 Georges Scelle, "La représentation politique," Revue du droit public 28 (1911): 547.

78 Articles 5-6 of the law of Mar. 27, 1907, extended voting and electability to women. See René Bloch and Henry Chaumel, Traité théorique et pratique des conseils de prud'hommes (Paris, 1925), 10; and Maria Vérone, Appel à la justice adressé par le Conseil national des femmes françaises à la Chambre des députés et au Sénat (Paris, 1909), 9. 
their proposal was simple: "Women can be nominated as judges on the same condition as men." They argued that new recruits were desperately needed to fill present and projected staff vacancies, and they called for the equal treatment of women in the workforce. Bardon, whose wife was a lawyer, also declared: "Woman has a place in the courts. In the tribunaux pour enfants, she will undoubtedly do better than the sexe fort as a judge, and her instincts for justice and motherliness will catalyze the justice system to become more just." ${ }^{99}$ The socialist Paul Ramadier (later the first prime minister of the Fourth Republic) defended the proposal, arguing that the courts would provide the best career for "feminism" to be "progressively and methodically" disseminated.

In the ensuing discussion deputies questioned women's legal eligibility to serve in public office and reiterated the old anxiety that women's entrance into the judiciary might result in women's abandonment of the foyer. As if to soften the sting of his disapproval, the deputy Pierre Colomb praised the beauty of women by quoting Cyrano de Bergerac before declaring that France was not ready for female judges because "the right to judge is one of the most serious, and there are many things to grant to women before deciding on her admission to the magistrature." Colomb's opposition was rooted in the belief that the judiciary was graced with a quality of souveraineté publique that made it impossible to grant women "the right to judge" before "the right to vote." He proclaimed that prioritizing judicial rights before suffrage was "illogical and premature" and that to do so failed to respect the gradual "stages" of women's "civic education." 80 The minister of justice, Raoul Péret, also rejected the proposal, cautioning the deputies that they had not looked at the consequences that approval would precipitate. He envisioned a slippery slope: "Will you admit them to the ministerial offices of avoués, notaires, greffiers? Will they be permitted in the prefectorial administration to become engineers of roads and bridges, to enter, in a word, all of public administration?" 81 Heeding his warning, the deputies voted down the amendment 378 to 200.

The jurist Louis Saint-Laurens claimed this vote as a victory for traditionalists. He described the judiciary as "the last fortress, still intact, of our masculinisme judiciaire erected against the assaults of feminism." ${ }^{22}$ Grinberg responded to this news with disappointment tinged

79 JO, Débats parlementaires, Chambre des députés, Apr. 5, 1930, 1559-61. The chamber passed a proposal for the municipal vote brought by Raymond Poincaré in July 1927, but requests by the chamber in 1928 and 1929 did not move the Senate to take up the issue. See Siân Reynolds, France between the Wars: Gender and Politics (New York, 1996), 210.

80 JO, Débats parlementaires, Chambre des députés, Apr. 5, 1930, 1561.

81 Ibid., 1562.

82 Saint-Laurens, Accession de la femme, 13. 


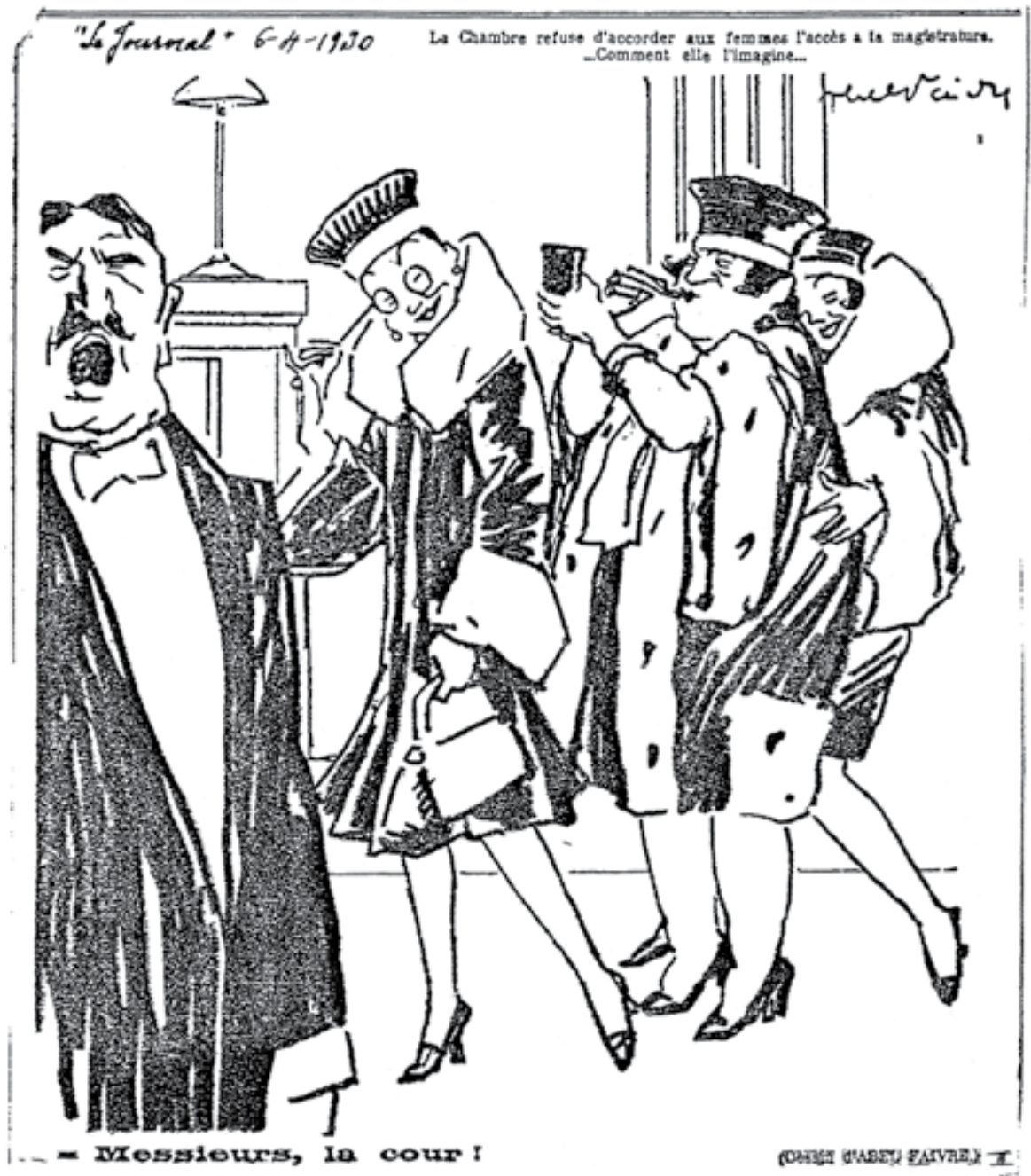

Figure 1 Abel Faivre, "Messieurs, la cour!” Le journal, April 6, 1930

with resentment, alleging that men lacked objectivity and fairness when confronted with professionally successful or authoritative women. ${ }^{83}$ Le journal echoed the controversy by publishing a caricature of three female judges, dressed in ermine-trimmed judicial robes, striding smilingly into a courtroom in high heels, waving demurely, and touching up their makeup (fig. 1). The humor of the image emerged from the 
juxtaposition of seemingly superficial women masquerading as judges. Such cartoonish women could never embody the ideal characteristics of judges such as rigor, impartiality, rationality, and authority. ${ }^{84}$ These stereotypes of female coquetry and lack of solemnity reified the National Assembly's rejection of equity.

The French judiciary was, in fact, facing a recruitment crisis. In 1926 Vérone noted that only 73 judges were promoted to fill 453 openings. By 1930 Bardon cited a need for 433 juges titulaires and another 79 supplementary ones. The National Association of Lawyers (Association Nationale des Avocats, or ANA) recognized the paucity of candidates for the magistrate's concours and debated the options at their 1930 meeting in Algiers. The majority favored lowering the minimum age for judicial candidates. Vérone argued passionately for the admission of women to the judiciary, remarking that more than two hundred women at the time worked at the Paris bar alone and that, following such a reform, the proportion of female law students would certainly increase from its current 12 percent. ${ }^{85}$ Anticipating that veteran avocates would seek places on the bench, Vérone counseled that it would be "much better to plead in front of a capable, competent, experienced woman" than to have one's case judged by a young, inexperienced, and less competent man. Although Vérone's cohort politely complimented her as individually remarkable, they rejected her recommendation and instead approved lowering the age qualification to twenty-three. The National Assembly promptly promulgated this proposal in the law of July $16,1930.86$

The ANA's refusal to approve women for the bench reflected a broader and intensifying antagonism toward the employment of women, notably married ones, during the interwar years. Susan Pedersen writes of the strong opposition of the Catholic Women's Civil and Social Union (Union Féminine Civique et Sociale, or UFCS), which "laid responsibility for virtually every social ill," from juvenile delinquency to falling birthrates, "at the feet of married women's work." 87 This loose

84 Abel Faivre, "Messieurs, la cour!” Le journal, Apr. 6, 1930.

85 Based on a total enrollment of 9,971 law students during the academic year 1929-30; Annuaire statistique de la ville de Paris, 1929, 1930 et 1931 (Paris, 1933), 533.

86 Maria Vérone, "Le congrès de Marseille," Le droit des femmes, Dec. 1930, 298-300; JO, Débats parlementaires, Chambre des députés, Apr. 5, 1930, 1559; Le congrès d'Alger de l'Association nationale des avocats (22-24 avril 1930), Bulletin de l'Association nationale des avocats inscrits aux barreaux de France, des colonies et pays de protectorat (Paris, 1930), 111-12.

87 Susan Pedersen, "Catholicism, Feminism, and the Politics of the Family during the Late Third Republic," in Mothers of a New World: Maternalist Politics and the Origins of Welfare States, ed. Seth Koven and Sonya Michel (New York, 1993), 246-76; Karen M. Offen, "Body Politics: Women, Work, and the Politics of Motherhood in France, 1920-1950," in Maternity and Gender Policies: 
coalition of Catholic groups, pronatalists, and doctors pressured married women to leave the workforce to make room for unemployed men. Although the position of the UFCS was extreme, those who supported women's right to work on the basis of necessity or fairness found themselves on the defensive, especially as the progress made on behalf of female white-collar workers met serious setbacks. Most significantly for the public sector, the prefect of the Seine had instituted gender-based quotas on the concours for rédacteurs (chief editorial clerks) in 1929; these quotas were followed by restrictions on women's employment in other central administration ministries. ${ }^{88}$

Cognizant of this antagonistic climate, women's rights advocates pursued another avenue to judicial access by approaching the supreme court of administrative justice, the Conseil d'Etat. Marie-Madeleine Dauvet-Thiénot, an experienced lawyer and the leader of the French Union for Women's Suffrage (Union Française pour le Suffrage des Femmes, or UFSF) in Troyes, was nominated for the bench in 1932. The justice minister responded to Dauvet-Thiénot's application by restating her ineligibility based on her sex. ${ }^{89}$ A year earlier her exclusion might have been justified by her failure to fulfill military service (an impossibility for women), except that this requirement for civil servants was abolished in $1931 .{ }^{90}$ Instead, the Conseil d'Etat's decision sustained the prohibition on women by harking back to the 1810 regulations of the legal profession, which in fact had never engaged this question. The Conseil d'Etat also reiterated the spirit of the 1900 law by claiming that women "could never be called to complete the courts or tribunals in an act of replacing absent judges." ${ }^{11}$ Dauvet-Thiénot countered that this decision was patently unjust. After all, she noted, avocates had the same requirements of service and duties as male lawyers, including paying professional taxes, yet they could not reap the same benefits, such as eligibility for professional advancement into the judiciary. ${ }^{92}$ Her appeal was to no immediate avail.

Women and the Rise of the European Welfare States, 1880s-1950s, ed. Gisela Bock and Pat Thane (London, 1991), 128-59.

88 Clark, Rise of Professional Women, 69-175.

89 Germaine Poinso-Chapuis, "Rapport de Mme. Poinso-Chapuis présenté au nom de la Commission de la justice et de la législation générale sur la proposition de loi de M. Robert Lecourt et plusieurs de ses collègues ayant pour objet de permettre aux femmes d'accéder à la magistrature (Rapport n. 523 annexe au procès-verbal de la séance du 6 février 1946)," Pouvoir judiciaire 11 (1956): 2.

90 Marcel Waline, Manuel élémentaire de droit administratif (Paris, 1936), 347.

91 Conseil d'Etat, Feb. 28, 1934, quoted in Verdeau, Accession des femmes, 94, 119. 1934.

92 Marie-Madeleine Dauvet-Thiénot, "Un verdict du Conseil d'état," La Française, Mar. 17, 
On another tack, defenders of women's rights argued in favor of the social benefits of women's work. Turning around the traditional opposition between work and domesticity, Jean Laroque, the procureur général from Caen, opined: "Women deserved to assume the sièges of justice; it is not in the name of a 'foyer in peril' that this opportunity is denied; on the contrary, it is to protect the household that women must be called to the judiciary. Are we alone in failing to understand that to segregate women from certain functions is not only an injustice but also a vehicle of prejudice in society?" 93 Using similar rhetoric, Juliette Veillier-Duray, the president of the French Association of University Women (Association des Françaises Diplômées des Universités, or AFDU), argued that work for women was not only a necessity but the principal mode for "intellectual and spiritual progress" in the world, a means for women to lead society toward greater perfection. ${ }^{94}$ Judge Rollet asked: "When will it be permissible for a young female lawyer to substitute for an absent magistrate in the juvenile courts?"95 These commentators defended the embattled belief that the justice system would benefit from women's greater participation in its workforce.

In the 1930s feminists formed a united front to combat the rising unemployment of intellectual workers and associated antipathy. The combined energies of the associations of female jurists (AFJ), university women (AFDU), and the labor section of the CNFF focused on opening careers to women, especially in the judiciary, the civil service, and the foreign service. ${ }^{96}$ The jurists' lobby, which claimed a membership of one thousand by 1937, took the initiative by organizing debates and publishing articles to stress the value of women's employment. ${ }^{97}$ They also directed support to Suzanne Borel, who in 1930 had been the first woman to pass the civil service exam to join the diplomatic corps; however, she had not been given a post befitting her qualifications on the grounds of her inferior civil status as a woman. Her ambitions frustrated, Borel remonstrated: "Few women are better placed than I to appreciate the cunning, often combined with treachery and persistence, employed by men to place obstacles in the path of those unfor-

93 Quoted in Maria Vérone, "Les femmes dans la magistrature," L'oeuvre, Oct. 8, 1932.

94 Juliette Veillier-Duray, "Le droit au travail," Bulletin de l'Association des françaises diplômées des universités 15 (1934): 4-9.

95 Henri Rollet, preface to Lévy, Auxiliaires du tribunal, 6.

96 "L'association des femmes juristes," LaFrançaise, Feb. 11, 1928; Odette Simon, "L'admission des femmes au concours de la diplomatie," La Française, Feb. 25, 1928.

97 "Comité de liaison pour la défense du travail féminin," La Française, Feb. 15, 1935; Germaine Sellier, "Les femmes dans la magistrature," La France judiciaire, May 17, 1931, 401. 
tunate women who stray from the beaten track." 98 In June 1930 Deputy de Monzie floated a bill to bring gender equality to civil employment, estimating that more than 300 women worked as lawyers in France and another 140,000 as state functionaries. ${ }^{99}$ His efforts, however, were unsuccessful.

The inauguration of Léon Blum's Popular Front cabinet in 1936, and with it the appointment of three female ministers, was a propitious sign to feminists that they finally had allies inside the government to facilitate their desired reforms. ${ }^{100}$ The attorney Marcelle KraemerBach hoped that the education undersecretary, Cécile Brunschvicg, would use her position to reactivate the proposal to secure equality in the judiciary. Brunschvicg, a founding member of the UFSF, was pessimistic. Earlier in the 1930s she had failed to persuade members of the Radical Party to support a resolution designed to open all public offices regardless of "class, sex, or opinion." ${ }^{101}$ She feared that the antifeminists would deploy arguments based on married women's civil incapacity to block any nomination of female judges. She thought compromises were possible, and she planned to push a parliamentary commission to accept women into the auxiliary staff of diplomatic offices. ${ }^{102}$ On the question of women's access to the judiciary, she was prepared only to ask the justice minister for his acquiescence to permit unmarried women into the juvenile courts to avoid a direct confrontation over married women's limited rights..$^{103}$

Subsequent parliamentary approaches to this issue were equally cautious. In January 1937 the war veteran and republican-socialist deputy Gabriel Delattre submitted a bill to give women entrée to the secondary position of juge assesseur in the juvenile courts. This measure would have permitted female lawyers with ten years' experience to apply for these secondary posts, or women aged twenty-five and older to sit for the magistrates' entrance exam. In his rationale Delattre argued:

98 Quoted in Simonton, History of European Women's Work, 242. Borel first assumed a diplomatic role as the wife of the foreign affairs minister Georges Bidault. Formal equality in the foreign service nominally resulted from the decree of June 6, 1945. See Elodie Lejeune, "Un retour aux normes? De Suzanne Borel à Madame Georges Bidault (1944-1953)," in Femmes et diplomatie: France-XXe siècle, ed. Yves Denéchère (Brussels, 2004), 75-92.

99 “Une proposition de loi de M. de Monzie," La Française, June 21, 1930.

100 On Cécile Brunschvicg, Suzanne Lacore, and Irène Joliot-Curie, see Sîan Reynolds, "Women and the Popular Front in France: The Case of the Three Women Ministers," French History 8 (1994): 196-224.

101 Cécile Brunschvicg, "De l'accession des femmes aux fonctions publiques," La Française, Nov. 5, 1932, quoted in Clark, Rise of Professional Women, 178.

102 Pierre Laval chaired the commission. See Cécile Brunschvicg, "Les femmes et la carrière diplomatique," La Française, Mar. 7, 1936.

103 Cécile Brunschvicg, "Accès des femmes aux emplois de la fonction publique," Centre des Archives du Féminisme, Angers, unpublished MSS, 1 AF 479. 
"Women are already lawyers, and in this position they can suggest solutions to the juvenile court, and since their contributions are demonstrably generous, understanding, [and] productive, why then can't they be permitted to collaborate in the drawing up of a sentence, the repercussions of which have a profound effect on the spirit and soul of a child?"104 The Committee on Civil and Criminal Legislation approved one restrictive version of Delattre's proposal that set a quota of two women per court in Paris and one per court in the provinces. ${ }^{105}$ Mireille Maroger, a criminal lawyer, endorsed this bill, insisting that women's innate maternal instincts made them infallible authorities on child welfare and claiming that women were better qualified than men to determine juvenile cases. ${ }^{106}$ Although Delattre's proposal fell short of the equality in principle that many feminists sought, Grinberg, for one, now supported any reasonable means to put women into the courts to aid atrisk children. Like Maroger, Grinberg emphasized women's distinctly feminine qualities, declaring that women possessed "hearts more merciful" than men's and "profound maternal instincts" that would save the "disinherited children" of France if they were given opportunities to judge. The approbation of female judges, she thought, would also improve France's status in the world by signaling a national commitment to the "fundamental principle of human justice." ${ }^{107}$ Delattre's proposal found approval at the committee level only and then faded from the political register. ${ }^{108}$ Full consideration of the issue would ultimately be delayed until after World War II and the liberation of France.

The pursuit of equality under the Vichy regime was incompatible with the authoritarian and repressive ideology of the new government. The regime demonstrated its commitment to revitalizing the nation through the family by restricting women's rights and idealizing women's traditional role in the domestic sphere. ${ }^{109}$ Acting to strengthen the patriarchal family, the law of October 11, 1940, curtailed women's right to work in civil service. The purging of women that followed was second

104 "Les femmes seront-elles juges-assesseurs dans les tribunaux pour enfants?" La Française, Jan. 23, 1937.

105 JO, Débats parlementaires, Chambre des députés, Jan. 14, 1937, 30; BMD, dossier Tribunaux pour enfants.

106 Mireille Maroger, "Ce sont les mères qui devraient juger les enfants," La Française, Nov. 13, 1937; Suzanne Normand, "Le souvenir de Mireille Maroger," Marianne, Nov. 11, 1937. Maroger was killed in a plane crash in Morocco in 1937 at the age of twenty-nine. $18,1937$.

107 Suzanne Grinberg, "Oui, ce sont des femmes qui doivent juger les enfants," Lundi, Jan.

108 JO, Débats parlementaires, Chambre des députés, Jan. 14, 1937, 30.

109 See Miranda Pollard, Reign of Virtue: Mobilizing Gender in Vichy France, 1940-1944 (Chicago, 1998). 
only to the persecution of Jews in exclusionary impact. ${ }^{110}$ This discriminatory law targeting only women proved untenable and was suspended after men were conscripted into the service du travail obligatoire (German labor service) in 1942. Vichy officials also drafted, but did not enact, the ordinance of July 27, 1942, that would have overhauled many features of the juvenile courts, including eliminating the role for defense lawyers that had generated admiration for women in previous decades. ${ }^{111}$

\section{The National Constituent Assembly}

Given the importance of the historical relationship between women's political rights and judicial access, it is no accident that women's admission to the bench occurred only after they were enfranchised. Frenchwomen acquired the right to vote by the decree of April 21, 1944, enacted by Charles de Gaulle. That same year the attorney Andrée Lehmann, Vérone's protégée and the postwar leader of the LFDF, demanded that the minister of justice, Pierre-Henri Teitgen, approve new legislation to open judicial posts. To feminists' dismay, the first bill introduced in January 1945 proposed restricting women to the magistrature assise, which would have meant excluding them from public prosecution and other elite offices. This limited bill, sponsored by the deputy Robert Lecourt, was sent to committee, where the deputy Germaine PoinsoChapuis, a Marseille attorney, did not let it reemerge without an overhaul. Concurrently, Poinso-Chapuis, the children's court commission chair Hélène Campinchi, and the socialist deputy Edouard Dupreux pressured the justice minister for equitable access. ${ }^{112}$

While a comprehensive plan to reform the judiciary languished, Campinchi, who was also an adviser to the justice commissioner, François de Menthon, drafted the February 1945 ordinance that modernized the TEA and opened posts to women. The promulgation of this decree permitted women over thirty, and of French nationality, to serve as juvenile magistrates. Addressing the plaguing problem of inadequate staffing, a change was instituted to the tutelary structure: one judge would now be assisted by two lay assessors, themselves experts in child welfare, who would be nominated by the garde des sceaux.113 Campinchi hoped that this reform would stabilize the courts, increase judges'

110 Linda L. Clark, "Higher-Ranking Women Civil Servants and the Vichy Regime: Firings and Hirings, Collaboration and Resistance," French History 13 (1999): 332-59.

111 On the 1942 ordinance, see Sarah Fishman, "Progressive Change in an Authoritarian Regime: Vichy's Reforms," in Battle for Children, 165-96.

112 Sylvie Chaperon, Les années Beauvoir (1945-1970) (Paris, 2000), 95-96.

113 JO, Ordonnances et décrets, Feb. 4, 1945, 530-34. 
expertise, expand the range of rehabilitation measures, and mandate a greater role for social workers. ${ }^{114}$ Poinso-Chapuis concluded that if the state truly intended to aid vulnerable children, then women ought to be put in control of the courts. ${ }^{115}$

Legislation mandating equal access to all other judicial jurisdictions finally came before the Constituent Assembly on June 12, 1945. The bill's champions, Marianne Verger, Robert Pimienta, and Lecourt, who were all recognized for their Resistance activities, argued that women should be given equal treatment in honor of their wartime patriotism and their persecution under the Nazis. They also celebrated women's accomplishments in teaching, scientific research, medicine, and journalism. Women seemed prepared for judicial decision making because they could now evaluate evidence as jurors and represent the people in the Constituent Assembly. The Radical deputy François Labrousse rejected these evocations of women's merits and called for their exclusion from the Cour de Cassation. Labrousse, who had opposed women's suffrage in 1922, insinuated that women were intellectually unfit for "abstract law" and were suited only for the children's courts. Most of his colleagues were not persuaded. Unable to secure modifications to the proposal, Labrousse stridently abstained from voting to signal his opposition. Remarkably, he carried fifty-four other delegates with him. ${ }^{116}$ These abstentions aside, the bill passed unanimously and became the law of April 11, 1946, that permitted all male and female citizens to apply for posts in the judiciary according to the same rules, whether by the concours or by nomination. Progress was possible, to paraphrase William Guéraiche, because the unity of the Resistance defeated the resistance of the antifeminists. ${ }^{117}$

\section{Tensions in the Postwar Period}

The number of women entering the judiciary immediately after the war was modest. Fewer than fifty women succeeded at the magistrates' exam between 1946 and 1949, resulting in a female presence of between 12 and 22 percent of the total candidates annually. ${ }^{118}$ The pioneering

114 Hélène Campinchi, "La réforme des tribunaux pour enfants," Le monde, Feb. 9, 1945.

115 Henriette Chandet, "Mme. Germaine Poinso-Chapuis: Députée des Bouches-duRhône," L'union nationale des femmes 15 (1946): 3.

116 JO, Débats de l'Assemblée consultative provisoire, June 12, 1945, 1092-95. The press misleadingly reported only unanimity, without noting the abstentions. See, e.g., "L'accession des femmes à la magistrature," Le monde, June 14, 1945.

117 William Guéraiche, Les femmes et la République: Essai sur la répartition du pouvoir de 1943 à 1979 (Paris, 1999), 63.

118 Ludovic de Boisbrunet, La justice des femmes: Essai sur la féminisation de la magistrature française (Paris, 2003), 66. 
cohort included Marguerite Haller and Charlotte Béquignon-Lagarde, who both completed doctoral theses in the mid-1920s and then became law professors. Haller began her new career by adjudicating war crimes cases in the Tribunal Général du Gouvernement Militaire in the French Zone of occupied Germany. Béquignon-Lagarde joined the Cour de Cassation and continued her successes. ${ }^{119}$ The exceptional achievements of these women illustrate how powerfully discrimination had constrained women's opportunities.

In this new era the grounds for women's legal equality found new security in the 1946 Constitution. Its preamble affirmed the equality of the sexes under the law and guaranteed the right to work. Public policy and social attitudes, however, continued to presume that women's place was primarily in the family. Feminists considered that vigilance was required to stand against the forces inclined to return society to prewar gender arrangements. ${ }^{120}$ The observant Moreau commented that the law of April 11, 1946, "like all innovations, was disputed; one whispered that certain people would want to restrain the application of the law to permit women to serve only as judges in the juvenile courts." ${ }^{21}$ Much as Moreau had feared, members of the Federal Union of Judges (Union Fédérale des Magistrats, or UFM) attempted to do just that when they voted with near unanimity to bar women from the position of procureur and to segregate them to the TEA. ${ }^{122}$ While this vote was nonbinding and impractical, it was an evident protest against the new gender order.

Two years later, in 1948, the UFM reinforced its threat of obstructionism by endorsing a decision by Paul Coste-Floret, then the minister for overseas departments and territories, who had prevented Madame Louys of Grenoble from sitting for the judiciary's concours. Coste-Floret had rejected Louys's application, insisting on his ministerial authority as the basis for denying her equal treatment. The Conseil d'Etat disagreed, ruling that Coste-Floret had abused his powers. That same year the legislature clarified that women were, in fact, eligible to serve in the supreme jurisdictions of the Conseil d'Etat and the Cour de Cassation, as well as in more mundane offices such as notary, bailiff, and court

119 Marguerite Haller, La femme dans la magistrature: Cour d'appel de Douai; Audience solennelle de rentrée du 16 septembre 1961 (Douai, 1961), 11. Béquignon-Lagarde received an honorary doctorate from Smith College in 1949 (Who's Who in France, 8th ed. [Paris, 1967], 786).

120 See Claire Duchen and Irene Bandhauer-Schöffmann, eds., introduction to When the War Was Over: Women, War, and Peace in Europe, 1940-1956 (London, 2000), 1-12.

121 Marie-Thérèse Moreau, "Au club féminin, avec Mme. Lagarde, conseiller à la Cour de Cassation,” L'union nationale des femmes 16 (1947): 5-6.

122 “Etats généraux de la magistrature française," Pouvoir judiciaire, Dec. 15, 1946, 6. 
clerk. ${ }^{123}$ Nevertheless, while those who studied the juvenile justice system called for seating at least one female judge in every court, the attitude toward women's employment again soured. ${ }^{124}$

Disappointed by their defeat in the Louys case, UFM members predicted that when women eventually did find work as judges in the colonies, "it is France who will pay." 125 Such dark prophesies coincided with the UFM's contemptuous descriptions of female judges as "assailants" who were decimating "our fortress." ${ }^{126}$ Moreover, they insisted that one legal weapon remained to keep women out of the judiciary that would require an act of solidarity by men: the evocation of puissance marital to prohibit their wives from working as judges. The law was on UFM's side. Regardless of the new Constitution and the Civil Code revisions of 1938 and 1943, a husband could still terminate his wife's employment for reasons of danger to her health or morality, of disruption to their cohabitation, the housekeeping, or her maternal role. ${ }^{127}$

The World War I veteran Robert Le Blant went farther by arguing that resistance to female judges must be sustained regardless of the law. At a professional assembly of the Court of Douai, Le Blant railed against women's employment as a destabilizing social force and hauled out old prejudices against women's intellectual capacity. His central point was the same as the UFM's, that a married woman made an unreliable judge because of puissance marital, which he described as a "veritable sword of Damocles that threatens to fall on the balances of Themis." 128 Indeed, feminists regretted that the Constitution had failed to override a variety of vestigial legal inequalities that still limited married women's rights. ${ }^{129}$ This conflict between formal equality for women, on the one hand, and the inequality for married women, on the other, prompted Moreau to demand: "But when will we see matrimonial law adapted to our Constitution and to the exigency of modern life? The legislature must act." ${ }^{130}$ Despite the overall climate of economic recovery and

123 Marie-Thérèse Moreau, "A propos de quelques propositions de lois: La femme célibataire; La femme notaire," L'union nationale des femmes 19 (1947): 3-4.

124 Margery Fry et al., The Juvenile Court: Measures to Be Taken (London, 1947), 186-87.

125 "Verrons-nous bientôt les femmes magistrates en pays musulman?" Pouvoir judiciaire, June 15, 1949, 5 .

126 Louis Aubin, "Ici l'on juge en robe . . . en en jupons," Pouvoir judiciaire, Jan. 15, 1947, 3. $79-105$.

127 André-Jean Arnaud, Les juristes face à la société du XIXe siècle à nos jours (Paris, 1975),

128 Robert Le Blant, La loi du 11 avril 1946 et les possibilités de mariage entre magistrats: Cour d'appel de Douai; Audience solennelle de rentrée du 2 octobre 1950 (Douai, 1950), 21-24.

129 Andrée Lehmann, Le 20e anniversaire de la Déclaration universel des droits de l'homme: Ce que les femmes doivent cette déclaration (Paris, 1968), 15.

130 Marie-Thérèse Moreau, "Chronique juridique: La femme auxiliaire de la justice; Une nouvelle loi," L'union nationale des femmes 24 (1948): 4-5. 
growth, women's rate of employment fell throughout the 1950s, and the disapproval of married women's paid employment continued. ${ }^{131}$

Although the contentiousness surrounding women and the judiciary in the colonial context merits a separate study, one example typifies the nature of the problem. Simone Gauillard (née Défix) passed the magistrates' exam in 1949 and sought a post in Dakar to join her spouse, a civil servant. The colonial minister did not support the employment of women in judicial functions and claimed that women were ill suited for jobs in the colonies because the conditions were difficult and because local traditions and religious beliefs were antithetical to accepting female authority. Nevertheless, members of the FIFGJ and the CNFF brought public pressure to bear on the ministry, and Gauillard finally received a satisfactory job in $1955 .{ }^{132}$ The following year, however, the tide turned against female judges in the colonies and territories. In the context of colonial upheaval, in which France had already lost control of Vietnam (1954) and was resisting the Algerian independence movement (1954-62), the Conseil d'Etat decided that all women could be barred from overseas judgeships because some civil service posts might require great physical strength or influence. ${ }^{133}$ During decolonization adherence to traditional manifestations of power proved more important than the recognition of legal equality.

\section{Conclusion}

This exploration of tensions engendered by the efforts to bring women into positions of authority in the judiciary leads to three conclusions. First, this history demonstrates the power of the argument that without political emancipation, women could not become eligible for the bench. If the judiciary was defined as a public office, by most measures women needed their formal political independence to participate. The law of 1900 that admitted women to the bar, but failed to make provisions for the expansion of professional rights, cast a long shadow over the discussions. Nevertheless, exceptions to this rule coexisted alongside the prohibitions, notably in the commercial and labor courts. Second, this research suggests that contemporaries concluded that the exclusion of women from the juvenile court judiciary weakened

\footnotetext{
131 Sylvie Chaperon, "La radicalisation des mouvements féminins français de 1960 à 1970," Vingtième siècle, no. 48 (1995): 62.

132 Yvonne Tolman-Guillard, "Accès des femmes à la magistrature coloniale," Robes noires 1 (1956): 29-30.

133 Robert Catherine, Le fonctionnaire français: Introduction à une déontologie de la fonction publique, new ed. (Paris, 1973), 63.
} 
the efficacy of the courts. Although there was little disagreement that women's supposed natural maternal instincts qualified them to oversee juveniles' welfare, the juvenile courts before 1945 struggled to establish their methods and purpose. ${ }^{134}$ Since World War II rehabilitation therapies have superseded punitive measures, and the juvenile courts have become feminized. Third, women's right to judge was not granted to acknowledge the equality of the sexes or to evoke women's special qualifications. Rather, this power was extended to recognize women's contribution to the Resistance and their suffering during the war and Occupation. In the postwar period conservatives continued to apply the brakes to progress; despite formal equality, men and women did not occupy the same positions, fulfill the same specialties, or enjoy equal status. ${ }^{135}$

At issue in this controversy were threats to corporate cohesion, traditional definitions of professional identity and practice, and male dominance in society. Whether or not women had a "right to judge" was a contest suffused with questions about the future of gender relations and the social organization of the nation. Feminists had hoped that if women's entrance into the judiciary preceded the extension of suffrage rights, then the bench would have provided a venue to demonstrate their aptitude as professionals and that this, in turn, would have raised the perceived value of women in society. The limited range of employment opportunities for women in the early twentieth century, along with the continued denial of suffrage after World War I, was a compelling sign that France was not keeping abreast of contemporary democratic trends in other industrial societies. Feminists' arguments for opening the judiciary to all women drew on the principle of equality, and the possibility that substantive social benefit would result from female judges' unique skills. However, neither the ideological claims nor the pragmatic problems posed by vacant posts during the interwar period proved sufficient to overcome traditional intransigence to changing the masculine judiciary.

Anxiety about the possibility of female judges prompted opponents to emphasize the difficulty of the job, recall women's legal disabilities, and insist that only men would suffice. Those Frenchmen who resisted equal political rights for women were also likely to reject advancing

134 Unfortunately, France suffered from increasing rates of juvenile crime throughout the interwar years, and during World War II the situation worsened, until rates of criminality were triple the prewar average. See Fishman, Battle for Children, 82-87.

135 In 2002 the proportion of women in the liberal professions and in the civil service had risen to 36-38 percent, a significant increase from the 11-19 percent they had occupied in 1962. See Margaret Maruani, Travail et emploi des femmes (Paris, 2003), 41-43. 
women's employment opportunities. It was convenient for antifeminists to maintain that women's ascension to the bench was premature in advance of suffrage reform. In the contest over women's access to the judiciary, it is clear that the struggle was more political than practical. As historians of women's history have amply demonstrated, political rights in France were fundamentally gendered in theory and application. ${ }^{136}$ The efforts to open the judiciary to women were met with a degree of resistance indicative of the larger political and social questions at stake. 